REVIJA ZA ELEMENTARNO IZOBRAŽEVANJE

JOURNAL OF ELEMNTARY EDUCATION

Vol. 13, No. 2, pp. 193-214, Junij 2020

Potrjeno/Accepted

9. 3.2019

Objavljeno/Published

8. 6. 2020

\section{THE WorldVIEW OF PrE-SERVICE AND IN-SERVICE TEACHERS ABOUT HEALTH EDUCATION}

\author{
ANDREJA ŠPERNJAK ${ }^{1} \&$ ANDREJ ŠORGO ${ }^{1}$ \\ 1 University of Maribor, Faculty of Natural Sciences and Mathematics, \\ Slovenia

\section{CORRESPONDING AUTHOR/KORESPONDENČNI AVTOR} \\ andreja.spernjak@um.si
}

\begin{abstract}
Izvleček Health is coconsidered as goodness; therefore, schools should be places where healthy habits, along with evidence-based medical knowledge and practices, are taught and practiced. The key persons in education are teachers, so their opinions and worldviews should not be neglected. The objective of this work was to identify opinions about health education among Slovenian teachers. We investigated the worldviews of and differences between pre-service and in-service Biology teachers about health education. The questionnaires were delivered to 163 Sloveian participants. Most differences in opinion occurred in the nutrition field between younger and older participants. The majority of participants $(85 \%)$ agree that "Providing knowledge or developing behavior that is respectful of one's own health" is the main goal of health education.

\section{Pogledi učiteljev in bodočih učiteljev na zdravstveno vzgojo}

Zdravje je zelo pomembna vrednota, zato bi v šolah učence morali poučevati in usposabljati za zdrav način življenja. To bi moralo temeljiti na medicinskih dokazih, znanju in dobrih praksah. V sistemu izobraževanja so ključne osebe učitelji, zato ne smemo zanemariti njihovih mnenj o zdravstveni vzgoji. Namen raziskave je bil pridobiti mnenja slovenskih učiteljev biologije in študentov biologije o zdravstveni vzgoji. Na vprašalnik je odgovorilo 163 slovenskih udeležencev. Razlike $\mathrm{v}$ mnenjih med mlajšimi in starejšimi udeleženci so bile vezane na mnenja glede prehrane. Večina udeležencev (85 $\%$ ) se strinja, da je »zagotavljanje znanja ali razvijanje vrednote lastnega zdravja« glavni cilj zdravstvene vzgoje.
\end{abstract}

Biohead-Citizen project, teachers' conceptions, Health Education.

Ključne besede: pogledi učiteljev, projekt Biohead-Citizen, zdravstvena vzgoja

UDK/UDC: 37:61:304.35 


\section{Introduction}

To wish someone good health is a traditional birthday or New Year's wish probably in all cultures around the world. However, for this wish to be realized, it should be supported by healthy habits at the personal level and medical support at the societal level. Because health is such an important and highly positioned value, some people may take a commercial or other kind of interest in it, not always on an honest basis. In addition, even when honestly meant, many suggestions for a healthy lifestyle do not necessarily follow the evidence and, what is worse, such advice can sometimes be worthless or even harmful (Brownson, Fielding, \& Maylahn, 2009; Waters, \& Doyle, 2002). Because of the great importance and serious consequences of health, everybody should be properly educated in finding and evaluating evidence about proposed practices that can sometimes be competitive. Such education should not be left to self-education and chance alone. Therefore, schools should be places where healthy habits, along with evidence-based medical knowledge and practices, are taught and reinforced. Because of rapid development in the field and information overload, teachers' knowledge about and attitudes toward health issues are not necessarily flawless. As a result, an amalgam of correct and incorrect knowledge and habits can be transferred into teaching practice. Given the theoretical worldview that actual behavior is the result of many predictors, among them opinions, preferences, perceived importance, perceived effort, motivation, self-efficacy and many others listed in classic theories (e. g. Ajzen 1991; Bandura, 1996; Deci, \& Ryan, 1985), any effort to change habits is challenging. Therefore, knowledge is vital, not only about the existence, but also about the strength of such factors affecting actual behavior, and this is the heart of the problem addressed in this paper.

The Universal Declaration of Human Rights (UDHR) has established "human rights as the foundation for freedom, justice and peace in the world" (Center for the Study of Human Rights, 1994, p. 1). If people neglect or violate just one of these rights, whether civil, political, economic, social or cultural, "this could have profound effects on health" (Cotter, Chevrier, El-Nachef, Radhakrishna, Rahangdale, et al., 2009, p. 1). Pommier, Jourdan, Berger, Vandoorne, Piorecka, and De Carvalho (2009, p. 183) found that "many European Union (EU) countries (including Slovenia) are striving to offer a high level of service, while striking a balance between viability and cost". These strategies affect school health promotion (Lear, 2002; Lee, Tsang, Lee \& To, 2003; Waggie, Gordon, \& Brijlal, 2004) and "can make a significant 
contribution to pupils' health and well-being" (UNESCO, 2005; UNICEF, 2006; WHO, 2003). To improve health promotion in schools in each country, various approaches have been adopted. Some approaches incorporate health promotion into the curriculum and teaching practice of regular teachers, while others involve healthcare services, such as school welfare services, and/or a combination of both. In promoting health, schools can sometimes make links to external professionals and local health services. Saint-Leger (1999, p.113) wrote, "Health services can be successfully involved in health programs if these are associated with the school program as a whole and if the work of the healthcare practitioners is complementary to that of other school professionals."

In a hectic lifestyle, one means for sustaining a rich and productive life is to ensure that people preserve and protect their own physical and mental health. According to Günay, Cavas, \& Hamurcu (2015, p. 142), societies comprising "healthy individuals are more successful and productive". Therefore, health issues must be given importance from early childhood and need to be geared towards an appropriate lifestyle, first in the family, then in school and prolonged as a lifelong set of values and habits. This is why some researchers draw attention to the importance of health education in schools for the prevention of unhealthy habits and the improvement of healthy ones (Inel, Günay, Evrekli \& Hamurcu, 2011; Jourdan, Samdal, Diagne, \& Carvalho, 2008). Teaching about and for health is complex, because health "education involves many issues, such as physical health and ways to protect it, adequate and balanced nutrition, drug abuse, sexual health, hazardous substances for health and working out" (Günay, et al., 2015, p. 142). Schools should enable students to build competence in taking action to improve their health by educating students about a healthy lifestyle (Aragâo, \& Sacadura, 2002; Kemm, \& Close, 1995; Pike, and Foster, 1995; Tones, \& Tilford, 2001). Health education should be included at all educational levels, from primary and lower secondary levels, to upper secondary general and vocational schools. It should be promoted as a trans-curricular and cross-curricular competence by all educators, regardless of their discipline, with the aim of promoting a healthy lifestyle as a lifelong attitude among their students. Only in such a way can learning about health issues be described as both a process and an outcome: evident and continuing change in knowledge or behavior. Teaching about health topics is not enough because "transfer of learning occurs when characteristics inherent to the students prompt them to demonstrate the competence (knowledge, skills, attitude and behavior)" (Botma, Van Rensburg, Heyns \& Coetzee, 2013, p. 
32). Therefore, teachers who are providers of "health education in schools not only need to have efficient and sufficient knowledge but should also serve as role models for their students" (Günay, et al., 2015, p. 142). Despite the complexity of health education, it should not be taught and promoted only by some teachers (e.g. Biology teachers) and health professionals (e. g. school nurses or invited professionals) because transfer of knowledge and skills, as well as attitudes concerning health are vital core competencies required by students and should be facilitated by all educators (Lauder, Sharkey, \& Booth, 2004).

\section{Health education in Slovenian schools}

Despite the growing understanding of the significance of the protection and promotion of health, formal health education in Slovenia is not at the appropriate quality level. "Teachers have a key role in the implementation and sustainability of effective health promotion in schools, but their health training is of paramount importance" (Jourdan, Pironom, Berger, \& Carvalho, 2012, p. 668). By checking core curricular documents for the Slovenian school system (program of elementary and secondary schools (2011)), one can recognize that health education was beyond the focus of the creators of these documents. For example, even in the White Book on Education in the Republic of Slovenia (2011), health education and its promotion are mentioned only as a general goal and are not further elaborated. From such evidence, one could conclude that the Slovenian elementary and secondary school curricula do not guide students sufficiently towards achieving knowledge about health, while gaining skills and experience in health issues.

In practice, health education is mainly delegated to Science and Biology teachers, where some learning goals and objectives are added mostly to Biology topics. For example, health education is incorporated into the syllabus of Biology in the 8th grade of elementary school, jointly with the anatomy and physiology of the human body. Slovenian 9-year compulsory elementary school programs, general secondary school programs and vocational programs do not have separate courses or subjects dedicated to health education. In the school subject Household (5th and 6th grade) can be found topics about health food, but this is just one aspect of health education. Some non-governmental organizations have identified the gap in health education and are implementing a revival of such a course in schools (Borovnik Lesjak, Šorgo, \& Strnad, 2019). Most Slovenian primary and secondary schools perform health 
promotion within the project Schools for Health in Europe network (SHE; 2017). The SHE network "aims to support organizations and professionals to further develop and sustain school health promotion in each country by providing a European platform for school health promotion" (SHE, 2017). According to SHE, promoting health in schools can support students in reaching the school's educational and social objectives. The advantages of health-promoting schools include better learning achievement; better health among students; better care for students; improved school atmosphere; higher job satisfaction; more action that is efficient and even a better school image (SHE, 2017).

The question is whether performance of health-education by the European SHE project is enough to provide students with health knowledge at a satisfactory level. The SHE project places no special stress on teachers' preferences in health education, which is very important in health education. Contrary to Slovenian practice, health education in Finnish schools, for example, is introduced at two levels. 'Firstly, by the national core curriculum and secondly by the individual curricula in each school" (Kuurala, Carvalho, Clement, Bogner, Kyllönen, Hänninen et al., 2006, p. 330).

Teachers must follow national curricula and syllabi, but they also have their own conceptions and value systems, which influence teaching practices in health education. Pommier et al. (2009) compared health education in seven European countries: Belgium, Denmark, France, Spain, Switzerland, Poland and Portugal. All seven countries have different approaches to health education, but the health services in these countries were mostly the same. Further evidence that teachers from different countries should not be taken as a uniform cohort is provided in studies by Šorgo et al. (2015) and Šorgo et al. (2017), leading to the conclusion that each entity should perform its own primary research on issues of interest.

\section{Purpose and aims of the research}

The aim of this study was to identify opinions about health education among educators in Slovenian schools. Special emphasis was given to preservice and inservice teachers of Biology. Our research questions were as follows: 
(1) Is there a difference in the mean scores for views about health according to the participants' status (pre-service teachers; students of primary non-pedagogical streams with the potential to become teachers in the future; in-service teachers and others employed in the field of education (non-teachers))?

(2) Is there a difference in the mean scores according to the participants' ages?

\section{Methodology}

The research method was a survey conducted among the target group (educators) using a questionnaire developed within the Biohead-Citizen project (2004-2008: Carvalho, Clément, Bogner, \& Caravita, 2008 and translated into the Slovenian language.

\section{Questionnaire}

The questionnaire in this study was assembled and validated within the BioheadCitizen research project (2004-2008: Carvalho, Clément, Bogner, \& Caravita, 2008). It contains 142 questions on 6 topics: Health Education; Human Reproduction and Sex Education; Ecology and Environmental Education; Human Brain; Human Genetics and Human Origin; and 16 questions related to personal information (gender, age, education, religion, religious opinions and so on). The English questionnaire was translated into Slovenian according to specific rules for controlled translation and validation. For this study, 21 questions concerning Health Education were used and four questions related to personal information (gender, age, level of education and occupation). In 14 questions, participants had to choose between "I do not agree" (1) and "T agree" (4) on a four-point Likert scale (Table 2): A52, B1, B2, B6, B9, B12, B15, B16, B21, B22, B23, B25, B26, and B27.

Question A55 used a semantic differential scale to measure the connotative meaning of things. Participants were asked to mark a number on a four-point scale between two options to express agreement or disagreement: Providing knowledge (1) vs. Developing behavior that is respectful of one's own health (4). 


\section{Questionnaire}

Completion of the questionnaires was anonymous (Clément, and Carvalho, 2007). In the Biohead-Citizen project, the questionnaire was aimed at pre- and in-service teachers with mainly academic backgrounds (Life Sciences, Home Language and other academic backgrounds). The Slovenian version of the questionnaire used in this investigation was provided on-line by the $1 \mathrm{ka}$ web service (https://www.1ka.si/). It was sent out by e-mail from September 20, 2016, to January 16, 2017, meaning a four-month collection period. We sent e-mails to preand in-service Science teachers (Biology, Chemistry and Physics) and Home Language teachers. The initial request was sent to 564 in-service and pre-service Biology and Slovenian language teachers from a mailing list assembled by the authors. They were asked to forward our request and questionnaire link to their colleagues, which yielded responses from persons who were not our primary target group. By the end of the collection period, 339 participants had started answering the questionnaire, and 163 participants had completed the whole questionnaire. The structure of the respondents was as follows: 130 (79.7\%) were females; 50 (39.5\%) were in-service teachers, $11(6.2 \%)$ pre-service teachers, 49 (27.7\%) students of nonpedagogical programs, and $30(16.9 \%)$ employed in education, but not in a teaching capacity. In the exploratory phase of the research (data not presented), it was revealed that statistical differences between sub-groups, even if significant, were present in only three items (A52, B6, B23); however, these were small and did not exceed the $r=0.3$ threshold levels for effect size, which allows us to consider our sample as representative of a homogenous group, at least when opinions about health in school are considered. Eighty-three percent of the in-service teachers are teachers of Biology or another Science subject (Physics or Chemistry). The other inservice teachers teach a variety of subjects such as Mathematics, Slovene Language, Foreign Language and Social Sciences, but none were teachers of Art or Sport. Because of the small statistical differences between subgroups established at the exploratory phase of the research, all participants were in most cases considered as a single group regarding their teaching fields.

Participants were divided into two age groups: those up to 35 years old comprised $109(61.6 \%)$ participants, and those over 36 years old comprised $53(30.2 \%)$ participants. One participant did not give her age. 


\section{Statistical procedures}

To answer the research questions, statistical analyses were performed with the IBM SPSS 22.0 statistical package. The statistical procedures employed were as follows:

Three questions (A52, B6 and B27) were presented as negations. In the appropriate statistical analysis, those three questions were reverse coded and are denoted $(\mathrm{R})$.

- for statistical analysis, variables were checked for normality with application of the Kolmogorov-Smirnov $\mathrm{Z}$ test (KS test) at the 0.05 significance level. Nonparametric statistics (Mann-Whitney and Kruskal-Wallis) was performed because not all variables followed normal distribution (Erceg-Hurn, and Mirosevich, 2008). Owing to skewed data distribution, mode and median are reported, and means and standard deviations to obtain a better impression of the central tendencies and data distribution. The reliability of the scales was explored by calculating the Cronbach's alpha and by further analysis with the 'alpha if item deleted' procedure in order to foresee potential improvements to the scales. Given the satisfactory alpha levels and to preserve the breadth of the scale, no items were deleted from a pool even if an increase in alpha was predicted.

Effect sizes were calculated by application of the formula $r=-z /$ sqrt $N$ (Field, 2013).

Principal Component Analysis with Direct Oblimin Rotation was used to explore the component structure of the attitudes toward health education in the school scales. Values of KMO (0.88) and Bartlett's test (Chi-Square $=755.67 ; \mathrm{df}=66 ; \mathrm{p}<0.001)$ permitted further analysis. Principal components with Eigenvalues above 1 and items with loadings above the 0.4 level are reported (Field, 2013), owing to the breadth of the reported findings; however, parallel analysis (Flora, and Curran, 2004) was the preferred choice to explore the number of components to be retained. Parallel analysis was calculated by an online engine (Patil, Singh, Mishra \& Donavan, 2017). Correlations were checked as part of the analysis provided by Factorial and Regression procedures. Pearson's correlation coefficients 
were calculated; coefficients below the 0.05 level (two-tailed) were considered significant.

A multivariate logistic regression model was used to evaluate the association between each variable and the dependent variable (view of health), while controlling for all other variables (Corder, \& Foreman, 2009).

Statistical significance was set at $\mathrm{p}<0.05$. Incomplete questionnaires were discarded. Questionnaires were kept anonymous, and participants involved in the research were all volunteers.

\section{Results}

Opinions about health education

Results for participants' opinions on 14 items about health education on a four-point scale are provided in Table 1. More detailed results about differences between participants' opinions are presented in Appendix 1. 
Table 1: Descriptive statistics about opinions on health education. Results are sorted by decreasing means of answers. $(\mathrm{N}=163)$.

\begin{tabular}{|c|c|c|c|c|c|c|c|c|c|c|}
\hline Items & & $\mathrm{F} 1 \%$ & $\mathrm{~F} 2 \%$ & $\mathrm{~F} 3 \%$ & $\mathrm{~F} 4 \%$ & Total & Median & Mode & Mean & SD \\
\hline B25 & I should eat more fresh vegetables. & 11.3 & 13 & 21.5 & 49.7 & 95.5 & 4 & 4 & 3.15 & 1.06 \\
\hline B12 & I would like to eat more fruit. & 12.4 & 12.4 & 29.4 & 42.4 & 96.6 & 3 & 4 & 3.05 & 1.04 \\
\hline B23 & Schools have to take into account public health policies. & 15.3 & 7.3 & 31.6 & 41.2 & 95.5 & 3 & 4 & 3.04 & 1.07 \\
\hline B16 & I should use olive oil more often in my food. & 11.3 & 19.2 & 34.5 & 31.1 & 96 & 3 & 3 & 2.89 & 0.99 \\
\hline B1 & Health Education at school improves pupil behavior. & 16.9 & 23.7 & 22 & 33.9 & 96.6 & 3 & 4 & 2.75 & 1.12 \\
\hline B2 & I would like to eat fish more often. & 22 & 26.6 & 34.5 & 13.6 & 96.6 & 3 & 4 & 2.72 & 1.12 \\
\hline B22 & $\begin{array}{l}\text { Teachers should not be obliged to teach health education } \\
\text { if they do not feel confident. }\end{array}$ & 22.6 & 20.3 & 27.1 & 26.6 & 96.6 & 3 & 3 & 2.6 & 1.13 \\
\hline B26 & $\begin{array}{l}\text { Health education at school mainly involves developing the } \\
\text { personal skills of pupils such as self-esteem or stress } \\
\text { management. }\end{array}$ & 13 & 36.7 & 35.6 & 10.7 & 96 & 2 & 2 & 2.46 & 0.86 \\
\hline B15 & $\begin{array}{l}\text { It is chiefly up to the school nurse and doctor to provide } \\
\text { health education. }\end{array}$ & 18.6 & 31.1 & 35.6 & 10.7 & 96 & 2 & 3 & 2.4 & 0.93 \\
\hline B9 & I would like to eat less meat. & 29.4 & 28.8 & 20.3 & 17.5 & 96 & 2 & 1 & 2.27 & 1.09 \\
\hline $\mathrm{B} 27_{(\mathrm{R})}$ & $\begin{array}{l}\text { It is exclusively the family's responsibility to deal with } \\
\text { health education. }\end{array}$ & 40.7 & 27.7 & 14.1 & 13.6 & 96 & 2 & 1 & 2.01 & 1.07 \\
\hline B21 & $\begin{array}{l}\text { Health education at school must be restricted to providing } \\
\text { scientific information (diet, sleeping cycle, drug risk). }\end{array}$ & 41.2 & 25.4 & 20.9 & 7.9 & 95.5 & 2 & 1 & 1.95 & 0.99 \\
\hline $\mathrm{B} 6_{(\mathrm{R})}$ & It would be good to put more fat in my food. & 42.4 & 31.1 & 9.6 & 14.1 & 97.2 & 2 & 1 & 1.95 & 1.06 \\
\hline $\mathrm{A} 52_{(\mathrm{R})}$ & $\begin{array}{l}\text { It is acceptable that poor people not have access to the } \\
\text { same health care quality as rich people. }\end{array}$ & 65.5 & 10.2 & 2.8 & 18.1 & 96.6 & 1 & 1 & 1.73 & 1.18 \\
\hline
\end{tabular}

Note. "I do not agree" (1) and "I agree" (4). Items denoted with R were reverse coded; however, in the table they are presented in the format as received.

The highest level of disagreement occurred with statement $\mathrm{A} 52_{(\mathrm{R})}$, where $65.5 \%$ of participants disagreed: It is acceptable that poor people not have access to the same health care quality as rich people. The highest level of agreement was given to statements B12, $\mathrm{B} 16$ and $\mathrm{B} 25$, which, together with disagreement with $\mathrm{B} 6_{(\mathrm{R})}$, indicates that participants are aware of the basic principles of healthy nutrition. 


\section{Opinions about health education}

Only in three items $\left(A 52, B 6_{(R)}\right.$ and B23) were statistically significant differences between different occupational subgroups identified (Appendix 2); however, effect sizes did not exceed medium levels.

Statistically significant differences $\chi^{2}=8.129 ; p=0.043$ were identified in item A52: It is acceptable that poor people not have access to the same health care quality as rich people. Pre-service and in-service teachers more frequently disagree with this item than respondents from non-pedagogical fields.

In item $\mathrm{B} 6_{(\mathrm{R})}$, It would be good to put more fat in my food, there were statistically significant differences $\chi^{2}=8.064 ; p=0.045$. In-service teachers more frequently disagree with item $\mathrm{B} 6_{(\mathrm{R})}$ than other groupsWith the item B23, Schools have to take into account public health policies, there were statistically significant differences $\chi^{2}$ $=10.059 ; \mathrm{p}=0.018$. In-service teachers more frequently disagree with item B23 than other groups.

\section{Differences in participants' opinions according to age}

Participants were separated by age into two groups: up to and including 35 years old and over 36 years old. Between these two groups, there were statistically significant differences in the following four items:

B6 (R): It would be good to put more fat in my food; $(U=2214.500 ; Z=-2.566 ; p(2-$ tailed $)=0.01)$. Effect size between groups is small $(r=0.26)$. Younger populations were statistically more in agreement with item $\mathrm{B} 6_{(\mathrm{R})}$.

B9: I would like to eat less meat; $(U=2107.500 ; Z=-2.738 ; p$ (2-tailed $)=0.006)$. Effect size between groups is small $(r=0.19)$. Younger populations were statistically more in disagreement with item B9.

B12: I would like to eat more fruit; $(U=2331.000 ; Z=-2.129 ; p(2$-tailed $)=0.033)$. Effect size between groups is small $(r=0.21)$. 
B25: I should eat more fresh vegetables; $(U=2166.000 ; Z=-2.566 ; p$ (2-tailed) $=$ $0.10)$. Effect size between groups is small $(r=0.21)$. Younger populations were statistically more in agreement with item B25.

\section{Principal component structure of attitudes toward health education in school}

Owing to the small differences between subgroups, PCA was performed only on the entire dataset. In our study, 14 items on opinions (Table 1) form three components that can be retained (Table 2 ) on the basis of Eigenvalue $>1$ criteria, and two on the basis of results from the parallel analysis. With the two remaining components (Table 2), 52.20\% of variance can be explained. Both components have appropriate Cronbach's alphas, as well. Items B1 (Health Education at school improves pupil behavior) and B2 (I would like to eat fish more often) loaded to the third component and, according to parallel analysis, should be discarded. Items B9 (I would like to eat less meat) and B26 (Health education at school mainly involves developing the personal skills of pupils such as selfesteem or stress management) did not load above the 0.4 level and were therefore also excluded from the pool.

Table 2: Rotated Component Matrix of participants' opinions.

\begin{tabular}{|c|c|c|c|}
\hline \multirow{2}{*}{ Items* } & \multirow{2}{*}{ Items } & \multicolumn{2}{|c|}{ Component } \\
\hline & & 1 & 2 \\
\hline B12 & I would like to eat more fruit & 0.75 & \\
\hline B22 & $\begin{array}{l}\text { Teachers should not be obliged to teach health education if they do not feel } \\
\text { confident }\end{array}$ & 0.75 & \\
\hline B23 & Schools have to take into account public health policies & 0.70 & \\
\hline B25 & I should eat more fresh vegetables & 0.69 & \\
\hline B16 & I should use olive oil more often in my food & 0.67 & \\
\hline $\mathrm{A} 52_{(\mathrm{R})}$ & $\begin{array}{l}\text { It is acceptable that poor people not have access to the same health care quality } \\
\text { as rich people }\end{array}$ & 0.63 & \\
\hline B15 & It is chiefly up to the school nurse and doctor to provide health education & & 0.83 \\
\hline B21 & $\begin{array}{l}\text { Health education at school must be restricted to providing scientific } \\
\text { information (diet, sleeping cycle, drug risk) }\end{array}$ & & 0.68 \\
\hline $\mathrm{B} 27_{(\mathrm{R})}$ & It is exclusively the family's responsibility to deal with health education & & 0.62 \\
\hline $\mathrm{B} 6_{(\mathrm{R})}$ & It would be good to put more fat in my food & & -0.55 \\
\hline & Explained variance & 40.95 & 11.25 \\
\hline & Eigenvalue & 4.91 & 1.35 \\
\hline & Cronbach's alpha & 0.85 & 0.72 \\
\hline
\end{tabular}


With the first component, we can explain $41 \%$ of variance (Cronbach's alpha $=$ 0.85). The first component combines mostly positive attitudes towards a healthy lifestyle. It comprises agreement by the majority of participants, who think that consuming appropriate food results in a healthier life, which can be regarded as a positive message, when transferring values to students. However, in Slovenian reality, foods like fruit, vegetables and olive oil are generally more expensive than complementary alternatives, which could cause a discrepancy between knowledge and actual behaviour. Positive messages include agreement with the statement that "Schools have to take into account public bealth policies" and disagreement with the statement "It is acceptable that poor people not have access to the same health care quality as rich people". The item "Teachers should not be obliged to teach health education if they do not feel confident," is important in the teaching of all subjects and targets the entire educational system, not just health education. Someone who does not feel confident in a subject cannot transmit knowledge in an appropriate way to the learners, and learners cannot acquire appropriate knowledge. However, about $40 \%$ of respondents do not agree with the statement, which was interpreted to mean that health issues should be taught under any circumstances. In fact, these responses reflect reality, because Health Education is left to the self-education of teachers, given that health education in practice is not part of their formal education even in Biology pre-service training, let alone for teachers in other areas.

The second component (Cronbach's alpha $=0.72$ ) explains $11 \%$ of variance and comprises four items $\left(\mathrm{B} 15, \mathrm{~B} 21, \mathrm{~B} 27_{(\mathrm{R})}\right.$ and $\left.\mathrm{B} 6_{(\mathrm{R})}\right)$. Item $\mathrm{B} 6_{(\mathrm{R})}$ "It would be good to put more fat in my food" loads negatively to the component, and because of the context of the other items, was excluded from commentary. The remaining three items centre on the concept of professionalism and leaving us with three items. The second component deals with the idea that health education should not be left exclusively to families, and that more than scientific information should be provided, leading us to the conclusion that schools should not only instruct about health, but offer more general education about it, as well. Opinion is divided about who should provide such education. 


\section{Opinions about the main goal of health education in school}

Item A55 (Table 3) was structured for participants to choose between two options on a differential scale, between F1: "Providing knowledge" and F4: "Developing behavior that is respectful of one's own health", and in this way to express their opinion about the main goal of health education in school. More than $85 \%$ of participants agree with the statement that "Providing knowledge or developing behavior that is respectful of one's own bealth" is the main goal of health education. Even more, no statistically significant differences were found between participants' occupations, showing the homogeneity of the opinion.

Table 3: Participants' opinions in question A55 and statistically significant differences by participants' occupation.

\begin{tabular}{lllllllllll}
\hline Question A55 & F1\% & F2\% & F3\% & F4\% & Median & Mode & Mean & SD & $\chi^{2}$ & $p$ \\
\hline $\begin{array}{l}\text { F1: Providing } \\
\text { knowledge; }\end{array}$ & & & & & & & & & & \\
$\begin{array}{l}\text { F4: Developing } \\
\text { behaviour that }\end{array}$ & 4.5 & 8.5 & 30.5 & 50.8 & 4 & 4 & 3.35 & 0.84 & 7.023 & 0.07 \\
is respectful of \\
one's own \\
health
\end{tabular}

However, opinions did statistically significantly differ between the two age groups $(U=10.54 ; p<0.001)$, even though the effect size is small $(r=0.19)$. Older participants believe that the main goal of health education in school is to provide knowledge, but younger participants, in contrast, believe that the main goal of health education in school is to develop behavior that is respectful of one's own health.

\section{Discussion and conclusions}

In this study, we investigated the conceptions among Slovenian participants (including pre- and in-service teachers, non-pedagogical students and other participants) regarding health education. The professional literature describes two paths of health education in schools, one based on the biomedical model, and the other on the social health model. In the Biohead-Citizen project, there were 19 participating countries, where health education was primarily taught in Biology 
classes. Because of this, a biochemical model of health education could be detected (biology facts), and this carried a risk that the teaching emphasized biology facts rather than social and psychological elements (Caussidier, Hage, Munoz, Remki, Larribi, and Khzami; 2011), although both are vital for basic and complete citizen health knowledge. Among Slovenian participants, there were significant differences in social and psychological health preferences. For in-service teachers, it is statistically unacceptable for poor people to lack access to the same health care quality as rich people. The reason most probably lies in the social component of teaching, reflecting that teachers should provide the same quality of knowledge to all students, no matter their social status. In-service teachers are statistically more in disagreement with the statement that schools have to take into account public health policies, which indicates that they are dissatisfied with the current status of such policies. Among Finnish pre- and in-service teachers, the principal goal of education is more to influence pupils' behavior than to provide scientific knowledge about health. Data on teachers' attitudes and values with regard to health issues is insufficient (Pommier et al., 2009). Because of the sociocultural variables of health education (e. g. the principal ones being religion and country of residence), it is important to know teachers' perceptions about health (Caussidier et al., 2011). For example, French teachers, more than Lebanese, Moroccan or Tunisian teachers, thought that health education improved the behavior of students and developed pupils' skills (Carvalho, Clément, Bogner, and Caravita, 2008). Behavior and skills are part of the social health model. This might suggest that French health education, based on the health promotion model, had an impact on these French teachers. Slovenian teachers have open ways of talking about health. Health education is dependent on their own health knowledge and personal conceptions about health. Another point of view emerged from the statement about nutrition and health, where more respomdents disagree that it would be good to consume more fat. Inservice teachers are statistically more in disagreement with this statement than other groups, which reflects the teachers' awareness of the health consequences of too much fat. In other participant's views about health education, there were no statistically significant differences.

Slovenian participants were separated by age, into a group 35 or below and a group over 36. Statistically significant differences between the age groups were found in the nutrition field. Younger participants were statistically more in agreement that it would be good to consume more fat. This can be interpreted as an awareness that 
we should not totally eliminate fat from the diet, although the fashion and advertising industries promote good health without fat. Younger participants are aware of the importance of fat for human health, but probably they do not consume it enough. Teacher awareness of fat consumption could be related to student awareness. Kobe, Štimec, Hlastan Ribič and Fidler Mis (2012), in the first Slovenian national representative study, found that the diet of Slovenian adolescents did not meet the recommendations for healthy eating. Between 2003 and 2005, adolescents between 15 and 16 years old did not consume enough vegetable oils. The older population in our research think that they consume enough fat.

The study among the Slovenian population showed a significant percentage of people who still have unhealthy nutrition habits (Koch, Gabrijelčič Blenkuš, Gregorčič \& Kostanjevec, 2014), which can be related to our study. The younger population in our study statistically agree that they would like to eat more fruit and vegetables. They probably do not eat enough fruit and vegetables but are aware of the importance of this for good health. Between the younger and older groups, there is a statistical difference in opinion about the quantity of meat consumption. The younger group disagree with the statement that they would like to eat less meat. Slovenian students mostly eat in fast food outlets or restaurants with a meat-based menu, so they can hardly imagine meals without meat.

Is "Providing knowledge" or "Developing behavior that is respectful of one's own bealth," the main goal of health education was the question under investigation. The majority of participants (85\%) agree with the statement that "Providing knowledge or developing behavior that is respectful of one's own health" is the main goal of health education. This shows that the socioeconomic model of education is the preferred option over the biomedical models. However, there does exist a gap, because recent Biology teachers lack appropriate training.

At the end of the Biohead-Citizen project, it was established that all 19 countries involved had health education and promotion strategies in schools, but very diverse personal approaches, methodology and quantity of health education. The variation in strategies for health education is influenced by many factors, like national and political beliefs, economic and health policy in each country, the role of health professionals, religion, different curriculums, institutional culture, school system organization and school physical and social environments. These are among the 
reasons that teachers' views on health education differ and have an important influence on teachers' beliefs and which textbooks they use. This study did not analyze the Slovenian syllabi and textbooks from a health education perspective, but this could be recommended for future research, as in the Biohead-Citizen project.

\section{Acknowledgements}

The authors reported no conflict of interest. The authors thank Pierre Clement and the Biohead-Citizen Project for their collaboration.

\section{References}

Ajzen, I. (1991). The theory of planned behavior. Organizational Behavior and Human Decision Processes, 50(2), 179-211.

Aragâo, M.J. and Sacadura, R. (2002). Guia Geral das Drogas: explicar o seu mecanismo e as suas consequências. ["General drug guideline: to explain their mechanisms and their consequences"]. Lisbon: Terramar.

Bandura, A. (1996). Self-Efficacy: The Exercise of Control. New York: W. H. Freeman.

Bela knjiga o VIZ v RS (2011). Retrieved from http://pefprints.pef.uni-li.si/1195/1/bela_knjiga_2011.pdf (Accessed: 25 ${ }^{\text {th }}$ November 2017)

Botma, Y., Van Rensburg, G.H., Heyns, T. and Coetzee, I.M. (2013). A concept analysis: Transfer of learning in Health Sciences Education. African Journal for Physical, Health Education, Recreation and Dance, pp. 32-43.

Borovnik Lesjak, V., Šorgo, A., and Strnad, M. (2019). Development, validation and assessment of the test on knowledge about basic life support and use of automated external defibrillator among schoolchildren. Scandinavian Journal of Trauma, Resuscitation and Emergency Medicine, 27(117), pp. $1-7$.

Brownson, R. C., Fielding, J. E., \& Maylahn, C. M. (2009). Evidence-based public health: a fundamental concept for public health practice. Annual Review of Public Health, 30, 175-201.

Carvalho, G.S., Clément, P., Bogner, F. and S. Caravita (2008). Biohead-Citizen: Biology, Health and Environmental Education for Better Citizenship, Final Report. Brussels: FP6, Priority 7, Project $\mathrm{N}^{\circ}$ CITC-CT-2004-506015.

Caussidier, C., Hage, el F., Munoz, F., Remki, L., Larribi, R., Khzami, S.E, Berger, D., de Carvalho, G. S., and Favre, D. (2011). In search of a health education model: teachers' conceptions in four Mediterranean countries. Global Health Promotion 1757-9759; 18(4), 5-15;

Center for the Study of Human Rights (1994). Universal Declaration of Human Rights: Twenty-Five Human Rights Documents. New York, NY: Columbia University Press.

Clément, P. and G. Carvalho (2007). Biology, Health and Environmental Education for better Citizenship: teachers' conceptions and textbook analysis in 19 countries. In: World Congress Comparative Education Societies, 13, "WCCES 2007: proceedings". Sarajevo, Bosnia-Herzegovina.

Corder, G.W., and Foreman, D.I. (2009). Nomparametric statistics for non-statisticians: A step-by-step approach. New Jersey: Wiley, 2009.

Cotter, L.E., Chevrier, J., El-Nachef, W.N., Radhakrishna, R., Rahangdale, L., Weiser, S.D., Iacopino, V. (2009). Health and Human Rights Education in U.S. Schools of Medicine and Public Health: Current Status and Future Challenges. PLoS ONE 4(3): e4916.

Curricular Documents of Slovenian School System (program of elementary and secondary schools; Retrieved from http://www.mizs.gov.si/si/delovna_podrocja/direktorat_za_predsolsko_vzgojo_in_osnovno_solstvo/osnovno_solstvo/ucni_nacrti/. (Accessed: 25 $5^{\text {th }}$ November 2017).

Deci, E. L., and Ryan, R. M. (1985). The general causality orientations scale: Self-determination in personality. Journal of Research in Personality, 19(2), 109-134. 
Erceg-Hurn, D. M. and Mirosevich V. M. (2008). Modern robust statistical methods: an easy way to maximize the accuracy and power of your research. The American Psychologist, 63(7), 591-601.

Field, A. (2013). Discovering Statistics Using IBM SPSS Statistics. Sage.

Flora, D. B., and Curran, P. J. (2004). An empirical evaluation of alternative methods of estimation for confirmatory factor analysis with ordinal data. Psychological Methods, 9(4), 466-491.

Günay, Y., Cavas, B., and Hamurcu, H. (2015). Pre-service Teachers' Views on the Environmental Education, Human Brain and Genetics, Health and Sexual Education. Procedia - Social and Behavioral Sciences, 167, pp. 141-151.

Inel, D., Günay, Y., Evrekli, E., and Hamurcu, H. (2011). Pre-service Teachers' Opinions about the Effects of Harmful Habits, Drug Use and Physical Activities on Human Health. Western Anatolia Journal of Educational Science, 349-358.

Jourdan, D., Samdal, O., Diagne, F. and Carvalho, G. (2008). The Future of Health Promotion in Schools Goes Through the Strengthening of Teacher Training at a Global Level. Promotion and Education, 15(3), 36-38.

Jourdan, D., Pironom, J., Berger, D., and Carvalho, G.S. (2012). Factors influencing teachers' views of health and health education: A study in 15 countries. Health Education Journal, 72(6), 660-672.

Kemm, J. R. and Close, A. (1995). Health Promotion: Theory \& Practice. London: Macmillan.

Kobe H., Štimec M., Hlastan Ribič C., Fidler Mis N. (2012). Food intake in Slovenian adolescents and adherence to the Optimized Mixed Diet: a nationally representative study. Public Health Nutrition, 15(4), 600-608.

Koch, V., Gabrijelčič Blenkuš, M., Gregorič, M. and Kostanjevec, S. (2014). Risk factors as a result of unhealthy nutrition in the adult population in Slovenia with regard to sociodemographic variables $=$ Dejavniki tveganja nezdravega načina prehranjevanja odraslih prebivalcev Slovenije glede na sociodemografske spremenljivke. Zdravstveno varstvo: Slovenian Journal of Public Health, 53(2), 144-155,

Kostanjevec, S., and Erjavšek, M. (2019). Pomen prehranskega izobraževanja otrok in mladostnikov za oblikovanje zdravih prehranjevalnih navad $=$ The importance of nutrition education for children and adolescents in their forming healthy eating habits. In: Živilstvo in prehrana med tradicijo in inovacijo $=$ Food science, technology and nutrition between tradition and innovation, 30. Bitenčevi živilski dnevi 2019 = 30th Food Technology Days 2019 dedicated to Prof. F. Bitenc, 19 June 2019, Ljubljana. 1. elektronska ed. Ljubljana: Biotehniška fakulteta, Oddelek za živilstvo. pp. 155-170.

Kuurala, S., Carvalho, G., Clement, P., Bogner, F.X., Kyllönen, T., Hänninen, O. and Ruma, A.L. (2006). Finnish pre- and in-service teachers' conceptions, values and teaching practices in health and environmental education. Human Perspectives on Sustainable Future, 99, pp. 330-336.

Lauder, W., Sharkey, S. and Booth, S. (2004). A case study of transfer of learning in a family health nursing course for students in remote and rural areas. Nurse Education in Practice, 4(1), 39-44.

Lear, J.G. (2002). Schools and adolescent health: strengthening services and improving outcomes. Journal of Adolescent Health, 31(6), 310-20.

Lee, A, Tsang, C., Lee, S.H., and To, C.Y. (2003). A comprehensive "Healthy Schools Programme" to promote school health: The Hong Kong experience in joining the efforts of health and education sectors. Journal of Epidemiologic Community Health, 57, $174-7$.

Patil, V. H., Singh, S. N., Mishra, S., \& Donavan, D. T. (2017). Parallel Analysis Engine to Aid in Determining Number of Factors to Retain using $\mathrm{R}$ [Computer software], Retrieved from https://analytics.gonzaga.edu/parallelengine/ (Accessed: 25 th November 25 2017).

Pike, S. and Foster, D. (1995). Health Promotion for All. London: Churchill Livingston.

Program of Elementary and Secondary Schools (2011). Retrieved from http://www.mizs.gov.si/si/delovna_podrocja/direktorat_za_predsolsko_vzgojo_in_osnovno_solstvo/osnovno _solstvo/ucni_nacrti/ (Accessed: 25 $5^{\text {th }}$ November 2017).

Pommier, J., Jourdan, D., Berger, D., Vandoorne, C., Piorecka, B., and De Carvalho, G.S. (2009). School health promotion: organization of services and roles of health professionals in seven European countries. The European Journal of Public Health, 1-7. 
Saint-Leger, L. (1999). Health promotion in schools. In: ECSC-EC-EAEC, The evidence of health promotion effectiveness: shaping public health in a new Europe. Part two. Luxembourg, 110-133.

Schools for Health in Europe Network (SHE). (2017). Retrieved from http://www.schools-forhealth.eu/she-network (Accessed: 25 th August 2017).

Šorgo, A., Pipenbaher, N., Šimić Šašić, S., Prokop, P., Kubiatko, M., Golob, N., Erdogan, M., Tomažič, I., Bilék, M., Fančovičova, J., Lamanauskas, V., and Usak, M. (2015). Cross national study on pre-service elementary and science teachers' opinions on science teaching. Eurasia Journal of Mathematics, Science and Technology Education, 11 (4), 713-723.

Šorgo, A., Lamanauskas, V., Šimić Šašić, S., Ersozlu, Z. N., Tomažič, I., Kubiatko, M., Prokop, P., Ersozlu, A., Fančovičova, J., Bilék, M., and Usak, M. (2017). Cross-national study on relations between motivation for science courses, pedagogy courses and general self-efficacy. Eurasia Journal of Mathematics, Science and Technology Education, 13(10), 6497-6508.

Tones, K. and Tilford, S. (2001). Health Promotion: effectiveness, efficiency and equity. Leeds: Nelson Thornes.

UNESCO (2005). Universal Declaration on Bioethics and Human Rights. Retrieved from http://portal.unesco.org/en/ev.phpURL_ID = 31058\&URL_DO=DO_TOPIC\&URLSECTION $=201 . h \mathrm{tml}$ (Accessed: $25^{\text {th }}$ November, 2017).

UNICEF (2006). Focusing resources on effective school health. Retrieved from https://www.unicef.org/lifeskills/index_7262.html (Accessed: 20th November, 2017).

Waggie, F., Gordon, N., and Brijlal, P. (2004). The school, a viable educational site for interdisciplinary health promotion. Education Health, 17, pp. 303-12.

Waters, E., \& Doyle, J. (2002). Evidence-based public health practice: improving the quality and quantity of the evidence. Journal of Public Health, 24(3), 227-229.

WHO. (2003). Framework Convention on Tobacco Control. World Health Organization. Retrieved from http://www.who.int/tobacco/framework/WHO_FCTC_english.pdf via the Internet. (Accessed: 25 th November, 2017).

WHO. (1986) Ottawa Charter for Health Promotion. First International Conference on Health Promotion, Ottawa [Internet]. 1986 [cited 2009 Dec. 4]. Retrieved from http://www.who.int/hpr/NPH/docs/ottawa_charter_hp.pdf (Accessed: 5th November 2017).

\section{Authors}

\section{Andreja Špernjak, PhD}

Assistant professor, University of Maribor, Faculty of Natural Sciences and Mathematics, e-mail: andreja.spernjak@um.si

Docentka, Univerza v Mariboru, Fakulteta za naravoslovje in matematiko, e-pošta: andreja.spernjak@um.si

\section{Andrej Šorgo, PhD}

Full professor, University of Maribor, Faculty of Natural Sciences and Mathematics, e-mail: andrej.sorgo@um.si

Redni profesor, Univerza v Mariboru, Fakulteta za naravoslovje in matematiko, e-pošta: andrej.sorgo@um.si 
Appendix 1

Appendix 1: Results of statistical tests for participants' opinions on health education based on participants' opinions.

\begin{tabular}{c|c|c}
\hline Items & Kruskal- Wallis test & $p$ \\
\hline B23 & 18.000 & 0.02 \\
A52 $_{(\mathrm{R})}$ & 43.000 & 0.04 \\
B6 $_{(\mathrm{R})}$ & 45.000 & 0.04 \\
$\mathrm{~B} 9$ & 85.000 & 0.08 \\
$\mathrm{~B} 25$ & 98.000 & 0.10 \\
$\mathrm{~B} 12$ & 265.000 & 0.27 \\
$\mathrm{~B} 2$ & 279.000 & 0.28 \\
$\mathrm{~B} 21$ & 318.000 & 0.32 \\
$\mathrm{~B} 22$ & 378.000 & 0.38 \\
$\mathrm{~B} 1$ & 636.000 & 0.64 \\
$\mathrm{~B} 27_{(\mathrm{R})}$ & 684.000 & 0.68 \\
$\mathrm{~B} 15$ & 747.000 & 0.75 \\
$\mathrm{~B} 16$ & 883.000 & 0.88 \\
B26 & 997.000 & 0.99 \\
\hline
\end{tabular}


Appendix 2

Appendix 2: Effect sizes for three items (A52, B6 $(\mathrm{R})$ and B23) with statistically significant differences between different occupational subgroups.

\begin{tabular}{|c|c|c|c|c|}
\hline & \multicolumn{3}{|l|}{ Items } \\
\hline & & $\mathrm{A} 52_{(\mathrm{R})}$ & $\mathrm{B} 6_{(\mathrm{R})}$ & $\mathrm{B} 23$ \\
\hline \multirow{6}{*}{$\begin{array}{l}\text { Effect } \\
\text { size }\end{array}$} & $\begin{array}{l}\text { Participants' occupation } \\
\text { subgroup }\end{array}$ & $\begin{array}{l}\text { It is acceptable that poor } \\
\text { people not have access to } \\
\text { the same health care } \\
\text { quality as rich people. }\end{array}$ & $\begin{array}{l}\text { It would be good to } \\
\text { put more fat in my } \\
\text { food. }\end{array}$ & $\begin{array}{l}\text { Schools bave to take } \\
\text { into account public } \\
\text { health policies. }\end{array}$ \\
\hline & $\begin{array}{l}\text { non-pedagogical } \\
\text { students and other non- } \\
\text { pedagogical participants } \\
\text { pre-service student } \\
\text { teachers and non- } \\
\text { pedagogical students }\end{array}$ & $\begin{array}{l}\text { small }(r=0.09) \\
\text { small }(r=0.12)\end{array}$ & $\begin{array}{l}\text { small }(r=0.09) \\
\operatorname{small}(r=0.05)\end{array}$ & $\begin{array}{l}\text { small }(r=0.08) \\
\text { small }(r=0.13)\end{array}$ \\
\hline & $\begin{array}{l}\text { pre-service student } \\
\text { teachers and in-service } \\
\text { teachers }\end{array}$ & small $(r=0.21)$ & $\begin{array}{l}\text { medium } \quad(r= \\
0.30)\end{array}$ & small $(r=0.28)$ \\
\hline & $\begin{array}{l}\text { pre-service student } \\
\text { teachers and other non- } \\
\text { pedagogical participants }\end{array}$ & small $(r=0.21)$ & $\operatorname{small}(r=0.13)$ & small $(r=0.04)$ \\
\hline & $\begin{array}{l}\text { in-service teachers and } \\
\text { non-pedagogical } \\
\text { students }\end{array}$ & small $(r=0.25)$ & small $(r=0.22)$ & small $(r=0.25)$ \\
\hline & $\begin{array}{l}\text { in-service teachers and } \\
\text { other non-pedagogical } \\
\text { participants }\end{array}$ & medium $(r=0.32)$ & $\operatorname{small}(r=0.29)$ & $\operatorname{small}(r=0.30)$ \\
\hline
\end{tabular}


